\title{
International Council for Standardization in Haematology (ICSH) Recommendations for Laboratory Measurement of Direct Oral Anticoagulants
}

\author{
Robert C. Gosselin ${ }^{1}$ Dorothy M. Adcock ${ }^{2}$ Shannon M. Bates ${ }^{3}$ Jonathan Douxfils ${ }^{4}$ \\ Emmanuel J. Favaloro ${ }^{5}$ Isabelle Gouin-Thibault ${ }^{6}$ Cecilia Guillermo $^{7}$ Yohko Kawai ${ }^{8}$ \\ Edelgard Lindhoff-Last ${ }^{9}$ Steve Kitchen ${ }^{10}$
}

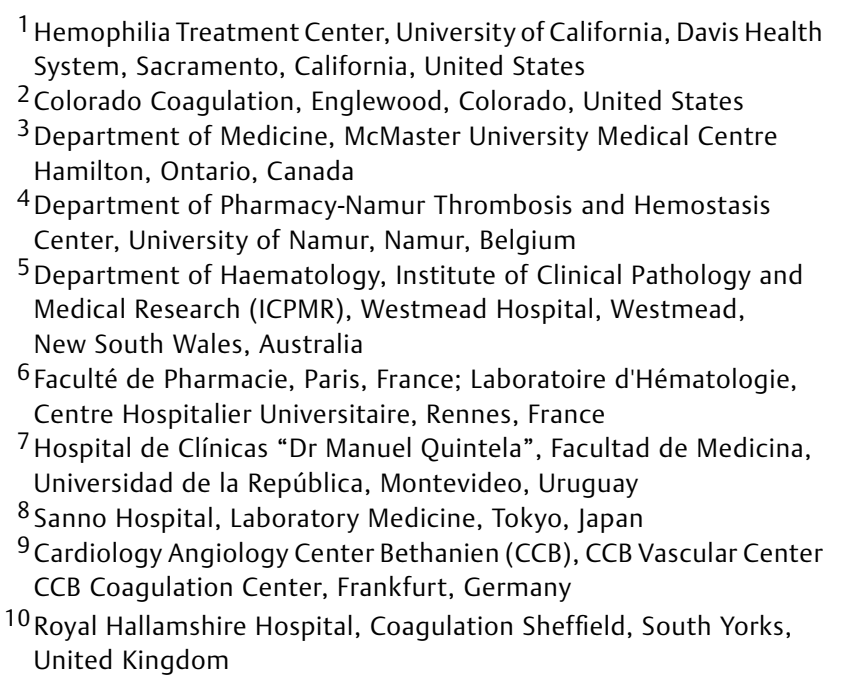

Address for correspondence Dorothy M. Adcock, MD, Laboratory Corporation of America Holdings, 531 South Spring Street, Burlington, NC 27215, United States (e-mail: adcockd@labcorp.com).

Thromb Haemost 2018;118:437-450.

\begin{abstract}
Keywords

- direct oral anticoagulants

- laboratory measurement

- laboratory guidance

- recommendations

This guidance document was prepared on behalf of the International Council for Standardization in Haematology (ICSH) for providing haemostasis-related guidance documents for clinical laboratories. This inaugural coagulation ICSH document was developed by an ad hoc committee, comprised of international clinical and laboratory direct acting oral anticoagulant (DOAC) experts. The committee developed consensus recommendations for laboratory measurement of DOACs (dabigatran, rivaroxaban, apixaban and edoxaban), which would be germane for laboratories assessing DOAC anticoagulation. This guidance document addresses all phases of laboratory DOAC measurements, including pre-analytical (e.g. preferred time sample collection, preferred sample type, sample stability), analytical (gold standard method, screening and quantifying methods) and post analytical (e.g. reporting units, quality assurance). The committee addressed the use and limitations of screening tests such as prothrombin time, activated partial thromboplastin time as well as viscoelastic measurements of clotting blood and point of care methods. Additionally, the committee provided recommendations for the proper validation or verification of performance of laboratory assays prior to implementation for clinical use, and external quality assurance to provide continuous assessment of testing and reporting method.
\end{abstract}

received

August 28, 2017

accepted after revision

December 21, 2017
Copyright () 2018 Schattauer

DOI https://doi.org/

$10.1055 / \mathrm{s}-0038-1627480$. ISSN $0340-6245$. 


\section{Background}

In 2008, the European Medicines Agency (EMA), an oversight agency for the European Union, approved the use of dabigatran etexilate (Pradaxa, Boehringer Ingelheim), an oral direct thrombin (factor [F]IIa) inhibitor, for thromboprophylaxis in patients after knee and hip replacement surgery. ${ }^{1}$ Since then, dabigatran and the direct factor Xa (FXa) inhibitors rivaroxaban (Xarelto, Bayer Pharma AG and Janssen Pharmaceuticals), apixaban (Eliquis, Bristol-Meyers Squibb and Pfizer) and edoxaban (Savaysa in the United States, Lixiana in Europe, Canada and Japan, Daiichi Sankyo) have been approved by the EMA and other regulatory agencies. Betrixaban (Bevyxxa, Portola Pharmaceuticals, Inc.), another antiXa direct acting oral anticoagulant (DOAC), was recently approved for VTE prophylaxis in the United States. However, as of this writing, there has been limited published data on the effect of this DOAC on laboratory assays.

Each DOAC has been reported to have predictable pharmacokinetic and pharmacodynamic responses, with no known dietary effect on efficacy, although food enhances the absorption of rivaroxaban. ${ }^{2}$ Unlike VKAs, DOACs do not require routine laboratory monitoring of anticoagulant activity, but emergent and nonemergent circumstances in which DOAC assessment may be required have been described. ${ }^{3}$ This publication serves as a technical International Council for Standardization in Haematology (ICSH) guidance document for laboratories that intend to assess (screen or quantify) DOAC anticoagulation. The recommendations provided are based on (1) information from peerreviewed publications about laboratory measurement of DOACs, (2) contributing author's personal experience/expert opinion and (3) good laboratory practice. This document will primarily address the laboratory assessment of dabigatran, rivaroxaban, apixaban and edoxaban. Consensus recommendations indicate agreement by all contributing authors.

Dabigatran Etexilate (Pradaxa, Boehringer Ingelheim) Dabigatran is formed when the oral prodrug, dabigatran etexilate, is hydrolyzed by esterases in the gut, liver, and blood. 2,4 Dabigatran competitively and irreversibly inhibits free and fibrin-bound thrombin by binding to the thrombin active site. ${ }^{2,4-7}$ Usually given twice daily, dabigatran dosing
( 75,110 or $150 \mathrm{mg}$ ) is based on indication, patient's age, and patient's renal function. ${ }^{2,8}$ There is low bioavailability (3$7 \%$ ), with $35 \%$ protein binding and $80 \%$ renal clearance. The time to reach maximum concentration is usually 1.25 to 3 hours after dose, with a half-life of approximately 12 to 14 hours in patients with normal renal function ${ }^{2-4,8,9}$ (-Table 1) Dabigatran is a substrate of efflux transporter P-glycoprotein (P-gp) (encoded by ABCB1) but is not metabolized by the cytochrome $\mathrm{P} 450$ isoenzymes. ${ }^{10}$

\section{Rivaroxaban (Xarelto, Bayer Pharma AG and Janssen Pharmaceuticals)}

Rivaroxaban is an oral, direct FXa inhibitor, inhibiting both free FXa and that bound to prothrombinase complex, thereby preventing thrombus extension. ${ }^{11}$ Rivaroxaban also inhibits FXa bound to the clot, in a concentration-dependent mechanism. ${ }^{12}$ Rivaroxaban is a competitive inhibitor of FXa, with high selectivity of more than 10,000-fold over other serine proteases. ${ }^{13}$ Rivaroxaban is absorbed rapidly, reaching peak plasma concentrations in 2 hours $^{14}$ ( - Table 1 ) and maximum inhibition of FXa activity between 1 and 4 hours after dosing. ${ }^{14,15}$ The half-life of rivaroxaban is 5 to 13 hours with high bioavailability $(80-100 \%)$ in the nourished state; however, rivaroxaban displays dissolution-limited absorption with decreased bioavailability in the fasting state. Plasma protein binding is approximately 92 to $95 \%$ with albumin as the main binding component. ${ }^{14}$ Rivaroxaban is a substrate of the efflux transporter P-gp and is metabolized by the CYP3A4 isoenzyme. ${ }^{16}$

\section{Apixaban (Eliquis, Bristol-Meyers Squibb)}

Apixaban is a direct, reversible inhibitor of FXa administered orally twice daily as active drug. ${ }^{2}$ In humans, eight metabolites have been identified, none of which appear to be active. ${ }^{17}$ Apixaban exhibits a half-life of approximately 12 hours, has a high affinity for FXa and inhibits free FXa, FXa in the prothrombinase complex and FXa bound to platelets (-Table 1). Absorption of apixaban is approximately 50\%. Following oral administration, peak plasma concentrations are observed about 3 to 4 hours post dosing. Apixaban is $87 \%$ bound to plasma proteins and is predominantly eliminated via the faecal route (56\%), with 25 to $29 \%$ of the recovered dose eliminated via renal excretion. ${ }^{18}$

Table 1 DOAC characteristics

\begin{tabular}{|l|l|l|l|l|}
\hline & Dabigatran & Rivaroxaban & Apixaban & Edoxaban \\
\hline $\begin{array}{l}\text { Mechanism of } \\
\text { action }\end{array}$ & $\begin{array}{l}\text { Direct, reversible inhibitor of free } \\
\text { and clot-bound thrombin }\end{array}$ & $\begin{array}{l}\text { Direct, reversible inhibitors of free and prothrombinase bound } \\
\text { factor Xa }\end{array}$ \\
\hline Bioavailability & $3-7 \%$ & $80-100 \%$ & $50 \%$ & $62 \%$ \\
\hline Protein binding & $35 \%$ & $92-95 \%$ & $87 \%$ & $55 \%$ \\
\hline Primary clearance & $80 \%$ renal & $67 \%$ renal & $56 \%$ faecal & $50 \%$ renal \\
\hline Tmax & $1.5-3 \mathrm{~h}$ & $2-3 \mathrm{~h}$ & $3-4 \mathrm{~h}$ & $1-2 \mathrm{~h}$ \\
\hline Half-life $^{\text {a }}$ & $12-14 \mathrm{~h}$ & $5-13 \mathrm{~h}$ & $12 \mathrm{~h}$ & $10-14 \mathrm{~h}$ \\
\hline
\end{tabular}

Abbreviation: Tmax, time to peak drug concentration after dose.

${ }^{a}$ Half-life varies with renal function, with increasing half-life with increased renal impairment. 
Apixaban is a substrate of the efflux transporter P-gp and is metabolized by the CYP3A4-isoenzyme. ${ }^{19}$

\section{Edoxaban (Savaysa in the United States, Lixiana in Europe, Canada and Japan, Daiichi Sankyo)}

Edoxaban is a highly selective, direct and reversible inhibitor of FXa. ${ }^{20,21}$ Edoxaban inhibits free FXa, as well as that within the prothrombinase complex. The recommended dose varies by indication and renal function ${ }^{21-29}$ (-Table 1). Edoxaban is absorbed rapidly with peak plasma concentrations within 1 to 2 hours and exhibits a half-life of 10 to 14 hours. ${ }^{20,21}$ The absolute bioavailability is approximately $62 \%{ }^{20,21}$ In vitro plasma protein binding is approximately 55\%. Unchanged edoxaban is the predominant form in plasma and this compound is metabolized via hydrolysis (mediated by carboxylesterase 1$)$, conjugation or oxidation by CYP3A4/5 $(<10 \%){ }^{20,21}$ Edoxaban has three active metabolites; the predominant metabolite (M-4), formed by hydrolysis, is active. Edoxaban is a substrate for the efflux transporter P-gp. ${ }^{20,21}$

Consensus DOAC measurement recommendations: general patient considerations.

- If nonemergent testing is necessary, recommend trough drug level assessment (-Table 2).

- Recommend DOAC levels be reported in ng/mL units.

- Recommend a comment with each reported DOAC result to indicate lack of DOAC 'therapeutic ranges', but cite expected trough levels (correlating with dose) for DOAC-treated patients from published studies ( - Table $\mathbf{2}$ ).

\section{Laboratory Assessment of DOACs}

The optimal laboratory method to measure a DOAC depends on whether the test(s) are used for qualitative (presence or absence) or quantitative $(\mathrm{ng} / \mathrm{mL})$ purpose, and the required turn-around-time (TAT) for result. ${ }^{3,30}$ Automated coagulation analysers have the capacity to quantify or screen for DOACs; however, both laboratory staff and treating clinicians require a thorough understanding of the limitations of the available assays, especially those used for qualitative purposes. Timely evaluation is critical in several scenarios such as life-threatening bleeding or acute stroke management. $^{31}$ As centralized hospital laboratories may take up to 1 hour to provide the results of routine coagulation parameters and possibly longer for DOAC concentration, appropriately validated point-of-care testing (POCT) methods should be considered if laboratory result TAT is not suitable for clinical urgency (see 'Other Screening Assays' section).

Consensus DOAC measurement recommendations: general laboratory considerations.

- Proper validation of any method used to quantify DOACs is required prior to clinical use of these assays (see the following sections).

- Recommend laboratories perform Internal Quality Control (IQC) at least once daily during testing performance, or at the minimum frequency required by regulatory agencies.

- Recommend enrollment in established External Quality Assurance program (EQA) (see the following section).

\section{Sample Requirement for DOAC Assessment}

Most data generated for functional qualitative or quantitative DOAC assessment have used sodium citrate samples, but comparisons of serum samples to plasma samples have been reported for rivaroxaban and apixaban. ${ }^{32}$ Serum measurements

Table 2 Expected peak and trough DOAC concentrations in patients treated for stroke prevention in NVAF or treatment of PE/VTE ${ }^{1,4,14,15,19,26-28}$

\begin{tabular}{|l|l|l|l|l|l|l|l|l|}
\hline & \multicolumn{2}{|l|}{ Dabigatran } & \multicolumn{2}{l|}{ Rivaroxaban } & \multicolumn{2}{l|}{ Apixaban } & \multicolumn{2}{l|}{ Edoxaban } \\
\hline Indication & $\begin{array}{l}\text { Stroke } \\
\text { prevention } \\
\text { in NVAF }\end{array}$ & $\begin{array}{l}\text { Treatment } \\
\text { PE/VTE }\end{array}$ & $\begin{array}{l}\text { Stroke } \\
\text { prevention } \\
\text { in NVAF }\end{array}$ & $\begin{array}{l}\text { Treatment } \\
\text { PE/VTE }\end{array}$ & $\begin{array}{l}\text { Stroke } \\
\text { prevention } \\
\text { in NVAF }\end{array}$ & $\begin{array}{l}\text { Treatment } \\
\text { PE/VTE }\end{array}$ & $\begin{array}{l}\text { Stroke } \\
\text { prevention } \\
\text { in NVAF }\end{array}$ & $\begin{array}{l}\text { Treatment } \\
\text { PE/VTE }\end{array}$ \\
\hline Dose & $\begin{array}{l}150 \mathrm{mg} \\
\text { bid }\end{array}$ & $\begin{array}{l}150 \mathrm{mg} \\
\text { bid }\end{array}$ & $20 \mathrm{mg}$ qd & $20 \mathrm{mg}$ qd & $5 \mathrm{mg}$ bid & $5 \mathrm{mg}$ bid & $60 \mathrm{mg}$ qd & $60 \mathrm{mg}$ qd \\
\hline $\begin{array}{l}\text { Peak } \\
\text { concentration, } \\
\text { ng/mL }\end{array}$ & $\begin{array}{l}175^{\mathrm{a}} \\
(117-275)\end{array}$ & $\begin{array}{l}175^{\mathrm{a}} \\
(117-275)\end{array}$ & $\begin{array}{l}249^{\mathrm{b}} \\
(184-343)\end{array}$ & $\begin{array}{l}270^{\mathrm{b}} \\
(189-419)\end{array}$ & $\begin{array}{l}171^{\mathrm{c}} \\
(91-321)\end{array}$ & $\begin{array}{l}132^{\mathrm{c}} \\
(59-302)\end{array}$ & $\begin{array}{l}170^{\mathrm{d}} \\
(125-245)\end{array}$ & $\begin{array}{l}234^{\mathrm{e}} \\
(149-317)\end{array}$ \\
\hline $\begin{array}{l}\text { Trough } \\
\text { concentration, } \\
\text { ng/mL }\end{array}$ & $\begin{array}{l}91^{\mathrm{a}} \\
(61-143)\end{array}$ & $\begin{array}{l}60^{\mathrm{a}} \\
(39-95)\end{array}$ & $\begin{array}{l}44^{\mathrm{b}} \\
(12-137)\end{array}$ & $\begin{array}{l}26^{\mathrm{b}} \\
(6-87)\end{array}$ & $\begin{array}{l}103^{\mathrm{c}} \\
(41-230)\end{array}$ & $\begin{array}{l}63^{\mathrm{c}} \\
(22-177)\end{array}$ & $\begin{array}{l}36^{\mathrm{e}} \\
(19-62)\end{array}$ & $\begin{array}{l}19^{\mathrm{e}} \\
(10-39)\end{array}$ \\
\hline
\end{tabular}

Abbreviations: bid, twice daily; IQR, interquartile range; NVAF, non-valvular atrial fibrillation; PE, pulmonary embolism; qd, once daily; VTE, venous thromboembolism.

Notes: Other approved indications for DOACs include secondary prevention of PE/VTE, and post hip and knee replacement, which may have alternative dosing strategies. Additionally, changes in doses may occur after initiation phase of DOAC treatment. Consultation of regional DOAC labeling information is required before interpreting or using these peak and trough DOAC concentration data.

a Mean (25th-75th percentile).

${ }^{\mathrm{b}}$ Mean (5th-95th percentile).

${ }^{c}$ Median (5th-95th percentile)

${ }^{\mathrm{d}}$ Median (1.5 $\left.\times \mathrm{IQR}\right)$.

${ }^{\mathrm{e}}$ Median (IQR). 
tended to be higher than plasma measurements when chromogenic anti-FXa methods are used, ${ }^{32}$ although this was also influenced by the drug concentration and reagents used. Mass spectrometry assays have included serum, lithium heparin and EDTA anticoagulated samples. Urinary assessment of DOACs has also been described and will be detailed later.

Stability data generated for both functional assays (e.g. dilute thrombin time [dTT] or chromogenic anti-FXa) and mass spectrophotometry methods have been published using both contrived (in vitro DOAC spiked) and patient samples. ${ }^{33,34}$ For dabigatran, the stability in plasma at room temperature is 24 hours, without improved stability at refrigerated temperature $\left(5^{\circ} \mathrm{C}\right)$, but at 14 months when maintained at $<20^{\circ} \mathrm{C}$ (personal communication via email from Joann van Ryn, Scientist, Boehringer Ingelheim, July 2017). ${ }^{33,34}$ However, there is a 4-hour stability for dabigatran when using the thrombin time test. ${ }^{35}$ For rivaroxaban and apixaban, the stability of DOAC in plasma has been shown to be at least 8 hours at room temperature, 48 hours at $5^{\circ} \mathrm{C}$ and at least 30 days when maintained at $<20^{\circ} \mathrm{C} .{ }^{33}$ Edoxaban demonstrated an $18 \%$ reduction in measurement when maintained at room temperature for 24 hours, but is stable up to 2 weeks at refrigerated temperatures when assessed by mass spectrometry, ${ }^{34}$ but it is unclear whether this refrigerated stability also applies to functional anti-FXa assays.

Multiple freeze-thaw cycles of DOAC containing plasma have also been described, with three cycles demonstrating no-effect on the measurement of rivaroxaban and edoxaban using chromogenic anti-Xa or mass spectrometry methods. ${ }^{33,34}$ Data for assessment of apixaban and dabigatran are conflicting, ${ }^{33,34}$ although closer scrutiny would suggest no clinically significant differences with three thaw cycles.

Consensus sample recommendations for DOAC assessment:

- Plasma prepared from 3.2\% sodium citrate can be used for quantitative and qualitative clot-based and chromogenic assays. ${ }^{32-34}$ Liquid chromatography-mass spectrometry/ mass spectrometry (LC-MS/MS) can use serum or plasma. $^{32,34}$

- Citrated whole blood samples should be processed within 4 hours of collection.

- Plasma samples for dabigatran that cannot be tested within 24 hours of collection should be frozen (stability of 14 months or greater if maintained at $-20^{\circ} \mathrm{C}$ or colder) using monitored freezers or dry ice (personal communication via email from Joann van Ryn, Scientist, Boehringer Ingelheim, July 2017).

- For thrombin time testing (dabigatran), plasma samples are stable for 4 hours at room temperature. ${ }^{35}$

- Plasma samples for anti-FXa DOACs that cannot be tested within 8 hours of collection should be refrigerated (stability of 48 hours) or frozen (stability of 30 days or greater if maintained at $-20^{\circ} \mathrm{C}$ or colder) using monitored freezers or dry ice. 33,34

- Data would suggest that at least three freeze-thaw cycles could be performed without significant loss of activity. 33,34

\section{Qualitative Assays for DOAC}

Due to their direct anti-FIla or anti-FXa activity, DOACs can interfere with most clot-based haemostasis tests. Numerous studies performed using either spiked normal plasmas or ex vivo patient or healthy volunteer plasmas have shown that the DOAC effect on clotting assays depends on the reagent as well as drug, with wide inter-individual variability. Early recommendations suggesting that laboratories could locally assess DOAC sensitivity to PT and activated partial thromboplastin time (APTT) reagents using commercial calibrators and controls may not be optimal, as these materials are not optimized for clot-based screening assays. ${ }^{36}$ This practice may overestimate reagent sensitivity to DOACs due to matrix variations (e.g. biased result due to components other than targeted analyte, calibration material may have other than $3.2 \%$ citrate concentration) and thus provide false assertions that a normal PT and/or APTT infers DOAC absence. Coagulation inhibitors or endogenous changes in coagulation factor levels can also affect the PT and APTT, and therefore lack specificity for the measurement of DOAC anticoagulation.

Of note, special consideration is required for DOAC-treated patients who may be bridged with unfractionated heparin (UFH) or low-molecular-weight heparin in acute situations. Depending on renal function, in the first 24 to 36 hours, there may be an additive effect on screening tests, and in these circumstances, the laboratory should be able to provide alternative strategies (e.g. anti-Xa for dabigatran-treated patients and thrombin time for UFH-treated anti-Xa DOAC patients) for assessing heparin anticoagulation, if required.

\section{Prothrombin Time}

Dabigatran and rivaroxaban prolong the PT in a concentrationdependent manner with a wide variability among reagents. The PT is less responsive to dabigatran than to rivaroxaban, regardless of the thromboplastin used. ${ }^{7,30,37-48}$ The rivaroxaban concentrations required to double PT vary from 66 to $750 \mathrm{ng} / \mathrm{mL}$. The PT ratios corresponding to $120 \mathrm{ng} / \mathrm{mL}$ rivaroxaban vary from 1.15 to 1.56 , while those corresponding to $200 \mathrm{ng} / \mathrm{mL}$ of dabigatran vary from 1.31 to 1.88 , depending on the reagent used. ${ }^{39,40,46,47}$ The apixaban concentrations required to double the PT range from $480 \mathrm{ng} / \mathrm{mL}$ with the most sensitive reagent to over $1000 \mathrm{ng} / \mathrm{mL}$ with other reagents. ${ }^{2,48-50}$ The PT may be normal (ratio <1.20) with apixaban concentrations up to $200 \mathrm{ng} / \mathrm{mL}^{46,47,49,50}$ The PT is more sensitive than the APTT to edoxaban, with insufficient sensitivity at low on-therapy ( $\sim 30 \mathrm{ng} / \mathrm{mL})$ drug levels. ${ }^{51-53}$ The prolongation of the PT is concentration- and reagent-dependent, ${ }^{54,55}$ with edoxaban concentrations required to double the PT varying from 97 to $296 \mathrm{ng} / \mathrm{mL} .^{55}$

As international normalized ratio (INR) and the international sensitivity index (ISI) are based on VKA sensitivity, the PT should not be expressed as INR in patients treated with DOACs. ${ }^{56}$ Although efforts to standardize PT methods by creating an ISI for rivaroxaban, analogous to the ISI for VKAs, ${ }^{57}$ have been published, this practice has not been widely embraced and has not been demonstrated to be applicable to apixaban or edoxaban PT measurements. 


\section{Activated Partial Thromboplastin Time}

The APTT is prolonged in a nonlinear manner with increasing concentrations of dabigatran and rivaroxaban, with a lower sensitivity to rivaroxaban than with dabigatran. ${ }^{7,30,37-45}$ Commercial APTT reagents differ in their sensitivity, with a required dabigatran concentration of approximatively and $400 \mathrm{ng} / \mathrm{mL}$ to produce a twofold prolongation in the APTT. ${ }^{41,52}$ The APTT ratios corresponding to $100 \mathrm{ng} / \mathrm{mL}$ dabigatran vary from 1.43 to 1.71 and those corresponding to $200 \mathrm{ng} / \mathrm{mL}$ from 1.67 to 1.97. ${ }^{46,47}$ The APTT shows a concentration-dependent prolongation of clotting times followed by a plateau at approximately $200 \mathrm{ng} / \mathrm{mL}$ apixaban. ${ }^{50}$ After a single $60 \mathrm{mg}$ dose of edoxaban, the mean peak (1.5 hours after dose) APTT modestly increased from pretreatment APTT of 32.3 to 41.1 seconds. ${ }^{54}$

When combined, a normal PT and APTT measured with responsive reagents may exclude dabigatran concentrations above $50 \mathrm{ng} / \mathrm{mL}$ but fails to detect the presence of rivaroxaban at concentrations of $50 \mathrm{ng} / \mathrm{mL}$, and apixaban of up to $200 \mathrm{ng} / \mathrm{mL}$ in a substantial number of patients. ${ }^{47,52,58,59}$ Overall, the low sensitivity and specificity of the PT and APTT to DOACs suggests that the ability of these tests to quantify DOAC concentration is poor and reagent dependent.

Additional note on DOACs and other haemostasis assays: The knowledge of the impact that DOACs have on coagulation testing is vital to avoid misinterpretation of laboratory test results that may result in mismanagement, especially in bleeding patients. ${ }^{60,61}$ DOACs are known to impact PT and APTT, tests that are modified PT and APTTs (e.g. factor assays, factor inhibitor assays, clot-based protein $C$ or protein $S$ ), other clot based (e.g. dilute Russell's viper venom time) and chromogenic assays (e.g. antithrombin) $30,40-44,50,51,53,62$ (-Table 3).

Table 3 DOAC interference on coagulation assays $3,33,40,50,51,53,62,111,123,138$

\begin{tabular}{|c|c|c|c|c|c|}
\hline & \multicolumn{2}{|l|}{ Dabigatran } & \multicolumn{2}{|l|}{ Anti-Xa DOACs } & \multirow[b]{2}{*}{$\begin{array}{l}\text { Clinical impact } \\
\text { of reported test } \\
\text { result }\end{array}$} \\
\hline & Clot-based assays & $\begin{array}{l}\text { Chromogenic- } \\
\text { based assays }\end{array}$ & Clot-based assays & $\begin{array}{l}\text { Chromogenic- } \\
\text { based assays }\end{array}$ & \\
\hline $\begin{array}{l}\text { Relationship } \\
\text { between } \\
\text { prolonged } \\
\text { clotting time and } \\
\text { increased drug } \\
\text { concentration }\end{array}$ & $\begin{array}{l}\text { PT/INR } \\
\text { APTT }^{\mathrm{a}, \mathrm{b}} \\
\text { Thrombin time } \\
\text { Ecarin-based } \\
\text { assays }\end{array}$ & & $\begin{array}{l}\mathrm{PT} / \mathrm{INR}^{\mathrm{a}, \mathrm{b}, \mathrm{c}} \\
\text { APTT }^{\mathrm{a}, \mathrm{b}, \mathrm{c}}\end{array}$ & & $\begin{array}{l}\text { Diagnosis and/or } \\
\text { Management }\end{array}$ \\
\hline $\begin{array}{l}\text { Relationship } \\
\text { between DOAC } \\
\text { presence and } \\
\text { factitiously } \\
\text { decreased } \\
\text { reported result }\end{array}$ & $\begin{array}{l}\text { Fibrinogen }^{\mathrm{b}, \mathrm{d}} \\
\text { Factor activity }^{\mathrm{a}} \\
\text { (II, V, VII, VIII, IX, } \\
\text { X, XI, XII) }\end{array}$ & & $\begin{array}{l}\text { Factor activity }{ }^{\mathrm{a}, \mathrm{b}, \mathrm{c}} \\
\text { (II, V, VII, VIII, IX, } \\
\text { X, XI, XII) }\end{array}$ & $\begin{array}{l}\text { Factor VIII } \\
\text { Factor IX }\end{array}$ & $\begin{array}{l}\text { (Mis)Diagnosis } \\
\text { and/or } \\
\text { (Mis)Management }\end{array}$ \\
\hline $\begin{array}{l}\text { Relationship } \\
\text { between DOAC } \\
\text { presence and } \\
\text { factitiously } \\
\text { increased } \\
\text { reported result }\end{array}$ & $\begin{array}{l}\text { Inhibitor screen }{ }^{\mathrm{a}, \mathrm{b}} \\
\text { Inhibitor assay }{ }^{\mathrm{a} b} \\
\text { Lupus } \\
\text { anticoagulant }^{\mathrm{a}} \\
\text { Protein C activity }^{\mathrm{a}, \mathrm{b}} \\
\text { Protein S activity } \\
\text { APCR }^{\mathrm{a}, \mathrm{b}}\end{array}$ & $\begin{array}{l}\text { Antithrombin } \\
\text { (thrombin } \\
\text { substrate) }\end{array}$ & $\begin{array}{l}\text { Inhibitor } \\
\text { screen }^{\text {a,b,c }} \\
\text { Inhibitor assay } \\
\text { Lupus } \\
\text { anticoagulant } \\
\text { Protein C } \\
\text { activity }^{\mathrm{a}, \mathrm{b}} \\
\text { Protein S } \\
\text { activity }^{\mathrm{a}, \mathrm{b}} \\
\text { APCR }^{\mathrm{a}, \mathrm{b}, \mathrm{c}}\end{array}$ & $\begin{array}{l}\text { Antithrombin } \\
\text { (factor Xa } \\
\text { substrate) } \\
\text { UFH, LMWH or } \\
\text { heparinoids/ } \\
\text { pentasaccharide }\end{array}$ & $\begin{array}{l}\text { (Mis)Diagnosis } \\
\text { and/or } \\
\text { (Mis)Management }\end{array}$ \\
\hline No effect & Reptilase time & $\begin{array}{l}\text { Antithrombin } \\
\text { (factor Xa } \\
\text { substrate) } \\
\text { Protein C activity } \\
\text { (chromogenic) } \\
\text { Plasminogen } \\
\text { activity } \\
\text { Alpha-2- } \\
\text { antiplasmin } \\
\text { Factor XIII activity } \\
\text { FVIII activity }\end{array}$ & $\begin{array}{l}\text { Fibrinogen } \\
\text { Thrombin time } \\
\text { Reptilase time } \\
\text { Ecarin-based } \\
\text { assays }\end{array}$ & $\begin{array}{l}\text { Antithrombin } \\
\text { (thrombin } \\
\text { substrate) } \\
\text { Protein C activity } \\
\text { (chromogenic) } \\
\text { Free protein S } \\
\text { antigen } \\
\text { Plasminogen } \\
\text { activity } \\
\text { Alpha-2- } \\
\text { antiplasmin } \\
\text { Factor XIII activity }\end{array}$ & $\begin{array}{l}\text { None-desired } \\
\text { testing, when } \\
\text { clinically } \\
\text { necessary or } \\
\text { relevant }\end{array}$ \\
\hline
\end{tabular}

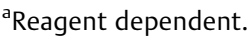

${ }^{b}$ Concentration dependent.

${ }^{\mathrm{C} A p i x a b a n}$ usually not affecting result.

${ }^{d}$ For fibrinogen-if measured using the Clauss method, most reagents will not be affected. For PT-derived measurements, results are more likely to be factitiously increased. 


\section{Other Screening Assays}

The TT is highly sensitive to dabigatran but is not affected by direct anti-Xa inhibitors. Dabigatran concentrations lower than $30 \mathrm{ng} / \mathrm{mL}$ lead to significant prolongation of the TT and concentrations of $50 \mathrm{ng} / \mathrm{mL}$ or greater typically produce a TT greater than the upper limit of measurement, depending on the reagent used. 2,35,63 A normal TT suggests that little or no dabigatran is present, but a prolonged TT does not necessarily equate to a high dabigatran level. ${ }^{2,3,63}$

\section{Point-of-Care Tests}

Viscoelastic measurements of clotting blood including the thromboelastograph (TEG) and rotational thromboelastogram (ROTEM) demonstrate that $\mathrm{R}$ times and clot formation times (CFT) correlated with dabigatran and rivaroxaban concentration. ${ }^{64,65}$ There was a strong correlation between rivaroxaban or apixaban concentrations and LowTF-ROTEM CFT and time to maximum velocity; ${ }^{66}$ yet, others report ROTEM as insensitive to detect residual rivaroxaban activity in patients. ${ }^{65,67} \mathrm{An}$ ecarin-base ROTEM has been recently reported to be sensitive to low levels of dabigatran. ${ }^{68}$ These viscoelastic measurements of DOACs perform better on peak samples, lose sensitivity for trough samples, with limited findings due to small sample size. $^{69,70}$ POCT methods (PT, APTT, activated clotting time [ACT]) for assessing DOACs have mostly been shown to have poor correlation, poor sensitivity or overlap between normal range and 'on-therapy' DOAC levels. ${ }^{48,59,71-73}$ A study using the Hemochron Signature POCT reported an INR cut-off for rivaroxaban of $\leq 1.0$ and $\leq 1.1$, respectively, equating to $<30$ and $<100 \mathrm{ng} / \mathrm{mL}$ of drug, and for dabigatran of $\leq 1.1$ and $\leq 1.2$, respectively, equating to $<30$ and $<50 \mathrm{ng} / \mathrm{mL}$ of drug. ${ }^{73}$ Items of concern with these reported cut-offs include (1) the requirement to know which DOAC is under investigation; (2) lack of method utility in apixaban-treated patients; (3) the fact that dedicated study personnel performed the POCT testing, which may not reflect real patient practice; (4) described INR cut-offs are below the normal published reference range (INR: 0.8$1.3) ;{ }^{74}$ and (5) the relatively high repeatability precision $(\sim 13 \%$ at a 2.1 INR) noted with this method. ${ }^{74}$

DOAC screening assays using urine samples have been evaluated, but no correlation was demonstrated between urine and plasma DOAC concentrations. ${ }^{75}$ A commercial urinary test screening for renal function (creatinine), anti$\mathrm{Xa}$ and direct thrombin inhibitor is soon to be released in Europe. ${ }^{76}$ Utilization of heparin-calibrated anti-FXa testing to potentially screen for the presence of anti-FXa DOACs will be discussed later.

Consensus screening test recommendations:

- The PT and/or APTT may not be reliable to detect the presence of 'on-therapy' concentrations of all DOACs. ${ }^{2,3,7,30,37-56,58,59}$

- PT and APTT are not responsive to 'on-therapy' apixaban levels. ${ }^{49-52}$

- The PT and APTT should not be used to quantify DOAC concentration. 2,3

- In a patient with known DOAC exposure, a prolonged PT or APTT should be considered secondary to drug effect until proven otherwise, and in emergent or life-threatening conditions, tests for quantifying DOAC should be performed to aid in patient management. 3,30

- A normal TT excludes the presence of significant dabigatran concentration. 2,3,30,63

- At the time of writing this article, there is not enough clear data to support the use of TEG or ROTEM for detecting DOAC anticoagulant activity. ${ }^{64-69}$

- Nonspecific POCT methods may not have sufficient responsiveness to detect DOAC presence. ${ }^{48,59,69-73}$

- Urine DOAC screening tests may provide a rapid assessment (qualitative and semiquantitative) of recent DOAC exposure, but may not reflect circulating drug presence or concentration. $^{75}$

\section{Quantitative Assays for DOAC Measurement}

The most accurate means of assessing DOAC exposure is by measuring concentration using LC-MS/MS or drug-calibrated clot-based or chromogenic methods. The availability and complexity associated with LC-MS/MS testing may limit its widespread use, whereas drug-calibrated clot-based or chromogenic methods can be adapted to automated coagulation analysers.

\section{Mass Spectrometry Measurement of DOACs}

The routine use of LC-MS/MS for the measurement of prescribed drugs in clinical laboratories has increased over the past 15 years and can be used to measure all DOACs. ${ }^{77,78}$ Due to its high degree of specificity, sensitivity, selectivity and reproducibility, LC-MS/MS is considered the gold standard method for the measurement of DOACs and is often used in clinical development to evaluate DOAC pharmacokinetics. ${ }^{8,79-82}$ The lower limit of detection (LLOD) and quantitation (LLOQ) for DOACs using LC-MS/MS has been reported to lie between 0.025 and $3 \mathrm{ng} / \mathrm{mL}$, depending on the method and the drug. The reportable range of quantitation has been described to be between 5 and $500 \mathrm{ng} / \mathrm{mL}$, which is suitable for expected peak and trough concentrations in most patients (-Table 2 ). The intra- and inter-assay precisions have been reported to be below 6 and 10\%, respectively. ${ }^{83-88}$

Several factors limit the widespread use of mass spectrometry in the clinical setting, including labour-intensive sample preparation steps, complexity of the technique and instrument availability. ${ }^{89}$ Additional assay challenges include matrix effect, co-elution of other compounds (drugs or xenobiotics), internal standard preparation and inadvertent detection or inability to detect drug metabolites (see below). These assays are mostly considered 'in-house' or laboratory-developed tests (LDTs), which may have additional method validation requirements as mandated by regional authorities (e.g. EMA, FDA).

With LC-MS/MS testing, the presence of phospholipids (PL), salts or molecules (e.g. such as surface-active compounds that can interfere with the droplet formation process in the ion sources) can cause a matrix effect. Plasma sample preparation (vs. serum) requires the removal of proteins, using protein precipitation with or without phospholipid 
removal. Solid-phase extraction (SPE) can provide a 'clean' sample for LC-MS/MS testing, and liquid-liquid extraction (LLE) methods for sample preparation can also be used.

In LC-MS/MS analysis, an internal standard is mandatory to compensate for variability of the response due to the ionization process and to the recovery during the sample preparation procedure. ${ }^{78}$ For DOACs, stable, isotope-labeled, standard versions are commercially available from several manufacturers. Additional considerations when developing an assay include (1) whether the drug must be metabolized to be functional, (2) possible interference by drug metabolites, (3) either co-elution of isotopomeric analytes or analytes that undergo in-source fragmentation to yield an isotopomers, (4) conversion of a metabolite to the parent drug during sample processing. Active metabolites should also be measured and reported. Dabigatran etexilate is a prodrug that must be metabolized to dabigatran to be fully functional. Furthermore, dabigatran exists in a free form and also conjugated to glucuronide. Dabigatran glucuronide adds approximately $20 \%$ anticoagulant activity. Alkaline hydrolysis of the sample prior to analysis splits the conjugate allowing measurement of total dabigatran. ${ }^{8,87} \mathrm{~A}$ similar pattern is seen with edoxaban and its M4-metabolite which is also pharmacologically active. ${ }^{82}$

Major limitations of LC-MS/MS include the absence of standardization or harmonization of mass spectrometrybased assays, ${ }^{90}$ and the lack of a universal calibration material or international reference standard. Significant variability between laboratories can be attributed to calibrators (matrix-based vs. solvent-based), calibrator source, sample preparation and the MS ion monitoring (ions selected in selected reaction monitoring or the use of high-resolution accurate mass spectrometry). ${ }^{91}$ Commercially available, high-quality reference materials, traceable to an international standard, are urgently needed for each DOAC to improve LC-MS/MS performance.

Consensus LC-MS/MS recommendations:

- LC-MS/MS should be considered the gold standard test for measuring DOAC concentration. ${ }^{8,79-82}$

- A suitable internal standard for each DOAC is mandatory. ${ }^{78}$

- DOAC metabolites, that are pharmacologically active, should be reported. $3,8,82,87$

\section{Other Methods for Quantifying Anti-Flla (Dabigatran) DOAC}

Published methods for measuring DTIs include the ecarin clotting time (ECT), chromogenic ecarin assay (ECA), chromogenic anti-FIIa (C-FIIa) assay, dTT and, to a lesser extent, the dilute Russell's viper venom time. Each of these methods can potentially be used for quantifying dabigatran, when calibrated appropriately.

\section{Ecarin-Based Methods}

Ecarin is a metalloprotease from saw-scaled viper, Echis carinatus, that converts prothrombin to meizothrombin, which can be inhibited by DTIs, but not heparin. The ECT reagent contains ( $\sim 5$ ecarin units $/ \mathrm{mL}$ ) ecarin, buffer (HEPES or Tris) and $\mathrm{CaCl}_{2}$, with equal volumes of reagent to plasma used for testing. ${ }^{92}$ For high drug concentrations, the patient plasma is diluted 1:1 with normal pooled plasma (NPP). The reported imprecision is less than $5 \%{ }^{92}$ Fibrinogen and prothrombin (factor II) deficiencies may impact the accuracy of the test. ${ }^{93,94}$ There is reported linear relationship between dabigatran concentration and ECT results and, with use of commercial calibrators, good correlation with LC-MS/MS measurements. ${ }^{95}$

The ECA pre-dilutes the patient sample with a buffer containing prothrombin to alleviate the prothrombin factor limitation as reported with ECT. As the ECA is not a clotbased assay, fibrinogen to fibrin formation is not measured, and thus, fibrinogen levels do not influence this assay. An equal volume of a substrate specific for thrombin cleavage is added to the diluted patient sample and incubated at $37^{\circ} \mathrm{C}$. An equal volume of ecarin is then added and the reaction is read either kinetically or over a fixed period of time. ${ }^{96}$ When the ECA is calibrated using commercial dabigatran material, there is good correlation with LC-MS/MS, ${ }^{91}$ reported LLOD ranging from 14 to $46 \mathrm{ng} / \mathrm{mL}$, within-run imprecision of less than $5 \% 83$ and between-run imprecision of 6 to $16 \%$ using quality control material. ${ }^{83,95,97,98}$

\section{Chromogenic Anti-Flla Assay}

Several commercial kits are available for measuring dabigatran using chromogenic anti-FIla assay (C-FIIa) methods. Similar to ECA, a substrate specific for thrombin is added to a neat or diluted plasma samples and incubated for a period of time ( $\sim 2$ minutes). A thrombin reagent is then added and the test is read either kinetically or the reaction stopped using an acid or alkaline solution. The kits may contain a heparin neutralizing agent that can be used in patients who are on transitional therapy. ${ }^{99}$ When the drug is calibrated, the C-FIla demonstrates good correlation with LCMS/MS $\left(R^{2}=0.96\right.$ for samples containing $<150 \mathrm{ng} / \mathrm{mL}$ dabigatran), with between-run imprecision of less than $5 \%$, and LLOD of approximately $15 \mathrm{ng} / \mathrm{mL}$, which can be further reduced with test modifications. ${ }^{35,97-99}$

\section{Dilute Thrombin Time}

First descriptions used one part plasma to three parts NPP. The final concentration of thrombin used was $0.75 \mathrm{NIHU} / \mathrm{mL}^{100,101}$ Equal volumes of diluted sample and thrombin are added, and clotting time recorded. When used in conjunction with drug calibrators, there is a linear relationship between clotting time and drug concentration. Commercial kits are available using same sample dilution with NPP (usually 1:8). ${ }^{94,95,97}$ In patients treated with dabigatran, a strong correlation between dTT and LC-MS/MS have been reported. ${ }^{84,97}$ Commercial assays report LLOD ranges of 2 to $8 \mathrm{ng} / \mathrm{mL}$ and LLOQ ranges of 20 to $30 \mathrm{ng} /$ $\mathrm{mL}^{83,97,101-104}$ Both LLOD and LLOQ can be improved with the use of a lower sample dilution with NPP and use of specific calibrators and controls (e.g. 1:2). ${ }^{97}$

Consensus anti-FIla (dabigatran) DOAC test recommendations:

- Demonstrated to be comparable to LC-MS/MS, drug-calibrated DTT, ECA, ECT and anti-FIla chromogenic methods 
are recommended as suitable methods to provide rapid quantitation of dabigatran. ${ }^{84,95,97,99,101,102}$

\section{Other Methods for Quantifying Anti-Xa DOACs}

\section{Chromogenic Anti-Xa Assay}

Chromogenic anti-Xa assay (C-FXa) assays have been used in the clinical laboratory for several decades as a means for assessing heparin anticoagulation. These assays are based on p-nitroaniline release from a specific chromogenic FXa substrate. The optical density generated per minute $(\mathrm{OD} / \mathrm{min})$ is inversely proportional to the amount of direct FXa inhibitor in the sample. Several in vitro and ex vivo studies have shown that C-FXa assays are very sensitive to the presence of direct FXa inhibitors. ${ }^{40,43,49,50,53,59,83,85,98,105-121}$ In vitro studies have shown that, for rivaroxaban, plasma samples with suspected levels less than $30 \mathrm{ng} / \mathrm{mL}$ may not be adequately assessed by C-FXa assays due to limited $\mathrm{LLOQ}^{40}$ while for apixaban and edoxaban, some authors reported lower thresholds (i.e. 15 and $10 \mathrm{ng} / \mathrm{mL}$, respectively). ${ }^{47,53}$ For rivaroxaban, an adapted procedure may be used to enhance sensitivity (i.e. the Biophen Direct Factor Xa Inhibitors LOW, Hyphen BioMed, France) to lower concentrations of drug, but may result in a decrease of the range of measurement. ${ }^{119}$ Thus, the assay sensitivity and LLOD/LLOQ threshold depends on the methodology and the C-FXa assay used, highlighting the importance of using a validated platform to assess the measurement of direct FXa inhibitors (- Table 2). Antithrombin supplementation of C-FXa kits leads to overestimation of direct FXa inhibitors and should be avoided. ${ }^{110,120}$

Ex vivo studies have highlighted limitations with rivaroxaban and apixaban measurement, with an LLOQ of around $30 \mathrm{ng} / \mathrm{mL}$ for both molecules. ${ }^{85,88,108,120}$ For edoxaban, an ex vivo study measuring the anti-Xa activity calibrated with heparin standards revealed a good correlation with LC-MS/ MS measurements. ${ }^{20}$ However, if comparison with LC-MS/ MS is required, the potential anti-Xa activity contribution of the M4 metabolite should be taken into account, since it is pharmacodynamically active and will interfere with the test, giving an elevated edoxaban concentrations in comparison to the LC-MS/MS measurement. ${ }^{53}$

A C-FXa assay calibrated with heparin standards can be used to inform on the relative presence of direct FXa inhibitors but is associated with a more limited range of linearity and quantitation. ${ }^{88,108,121-123}$ Results below the assay's LLOQ suggest that no or clinically insignificant concentrations of FXa DOACS are present. However, due to kit difference in chromogenic substrates, factor FXa origin, methodologies and heparin calibration, the use of heparincalibrated C-FXa assays should be used with caution. ${ }^{123,124}$ All heparin-calibrated methods may not be equally sensitive to a similar direct FXa level. ${ }^{124}$

Consensus anti-FXa DOAC test recommendations:

- Demonstrated to be comparable to LC-MS/MS; drugcalibrated anti-FXa is recommended as suitable methods to provide rapid quantitation of anti-Xa DOACs. ${ }^{40,43,49,50,53,59,83,85,88,105-118}$
- Antithrombin supplement anti-FXa methods should not be used for DOAC assessment, as these methods tend to overestimate drug concentration and are not validated by the manufacturers. ${ }^{110,120}$

\section{Point-of-Care Testing Assays and in Development Assays}

Unless institutions have the capacity to rapidly report (<30 minutes) DOAC concentrations using aforementioned calibrated laboratory assays on a daily or on-demand basis, specific whole-blood POC assays for DOAC quantification are urgently needed but not yet available. Harenberg et al have described results of a POCT qualitative and semiquantitative assay using urine samples of patients treated with dabigatran, rivaroxaban or apixaban. ${ }^{75,76,125-127}$ A miniaturized microfluidic coagulation test has been described for anti-FXa measurements; although specific for heparin anticoagulation, it may offer similar application for use in DOAC anticoagulation. ${ }^{128}$ More recently, another microfluidic method has been described in stroke patients. ${ }^{129}$ This POC method with sensitivity to warfarin, dabigatran and rivaroxaban, but not apixaban, employs surface acoustic waves that detect prolonged coagulation times. ${ }^{129}$ The SPOCT-NOAC trial ${ }^{130}$ is an ongoing investigator-initiated prospective trial which aims to test the correlation between the Cascade Abrazo POCT device (Helena Laboratories, United States) and plasma levels of apixaban, dabigatran and rivaroxaban, and to determine the diagnostic accuracy of POCT to rule out or detect relevant levels of DOACs in patient samples.

\section{Quantifying DOACs: Assay Validation or Verification of Performance}

Prior to offering a test for clinical use, the assay must be either verified or validated in the laboratory in which it is to be performed. Guidance documents have been published for industry ${ }^{131-133}$ and laboratories, ${ }^{134-136}$ although challenges to performing all studies due to limited resources (financial and staff) are acknowledged. An assay validation is required when the method is a standard (agency approved) method that is either modified or used outside the scope of the test, or a non-standardized test, or a LDT or research use only (RUO) assay. A verification of standardized assays (rather than full validation) may be a suitable approach for the laboratory to document it has achieved the reported testing performance. $^{135,136}$ The validation methods typically include accuracy (or trueness), precision (repeatability and intermediate [inter-assay] precision), specificity (selectivity), LLOD (DOAC level that is significantly different than zero), LLOQ (lowest DOAC measurement that meets acceptable performance criteria), linearity, range (reportable range) and stability. ${ }^{137}$ Verification of a standardized method typically includes precision, accuracy and possibly linearity. Accuracy may be inferred if the precision, linearity and specificity criteria have been established. ${ }^{132,133,137}$

A validation or verification of performance plan (protocol) must be developed and approved by the laboratory director 
(or delegate as appropriate). The plan should include processes to be performed (precision, linearity, etc.), the sequence of analysis, type of validation samples to be used, the number of runs to be performed over a specified (minimum) number of days and the quality control that will be utilized. The plan should describe the statistical analysis and acceptance criteria. A summary report, to include the validation data, intended use and reporting format of the DOAC assay, must be approved by the laboratory director (or designate), prior to clinical use ${ }^{131,136,137}$ and each laboratory must maintain validation or verification documentation.

\section{Validation Samples}

The materials used as validators can include a variety of sources, such as de-identified patient samples, ex vivo drugspiked plasma, quality control materials or calibrators. It is critical that the validation samples are of like-matrix to the patient samples that will ultimately be tested in the assay. ${ }^{131}$ Contrived, ex vivo DOAC samples must verify that the native drug is the active metabolite. For mass spectrometry assays, the measurement of active metabolites in addition to the parent compound must be considered. Validator samples should be representative of the samples that will be tested and should fall on the calibration curve, typically with one in the upper third of the curve, one in the mid portion and one on the lower third of the curve. ${ }^{131}$ If calibrators are used as validation samples, the lot used as validator material should either be from a different manufacturer source or a different lot than that used to calibrate the assay.

For chromogenic or clot-based quantitative DOAC assays, the first step in the process is the assay calibration and the criteria required for acceptable calibration curve. The calibration curve should cover the expected DOAC concentration and a calibrator sample near or at the LLOQ. ${ }^{131}$ Extrapolation of data above or below a calibration curve is not recommended. ${ }^{131}$ The validity of the calibration curve should be assessed by measuring samples with defined DOAC concentration limits. ${ }^{137}$ If the calibration curve and DOAC sample concentration steps are acceptable, within-run precision (repeatability) should be assessed. Different recommendations for intra-assay precision include a minimum of nine determinations covering the range (e.g. three replicates of three concentrations), or at least six determinations at a single level. ${ }^{132,133}$ For between-run precision, it has been recommended that LLOQ, low, mid and high validator samples from at least three runs are analysed on two different days. ${ }^{137}$ Limits have been described as a CV of less than $15 \%$, except at LLOQ where the limit would be less than $20 \%{ }^{131}$ Verification of performance repeatability limits should approximate manufacturer package insert or published data. Unacceptable within-run precision may suggest problems with instrument assay protocol definitions or possible reagent or sample carryover, if an automated analyser is used.

Linearity is determined using at least five to six samples tested over the reportable range. ${ }^{132-134}$ LLOQ and LLOD using standard deviation calculations have been described using samples with no drug (blank), blank samples compared with low concentrations of drug (signal/noise), or calibration intercepts. ${ }^{132-134}$ Alternatively, the deviation of more than $20 \%$ from low concentrations of drug can be determined from linearity studies. ${ }^{131}$ The replicate determinations for LLOQ and LLOD range from 6 to 10 samples. ${ }^{135,136}$

Accuracy, or trueness, is a measure of the closeness of the DOAC result obtained to the true measured (assayed or reported) value. A minimum of three levels of validator samples are required for accuracy studies, ${ }^{131}$ and these should include samples that fall on the lower one-third as well as upper one-third of the calibration curve. Validation samples should not fall outside of the standard curve. The acceptable limits for accuracy vary, but have been reported to be within $15 \%$ of measured value or within $20 \%$ of LLOQ, ${ }^{131}$ but other statistical analyses such as bias determination ${ }^{136}$ or paired $t$-test ${ }^{135}$ have been described. Dilution integrity may be evaluated if samples with DOAC concentrations about the upper limit of the calibration curve will be diluted with the appropriate matrix to obtain measurable results. Dilution should not affect precision and accuracy and these should fall within $\pm 15 \%$. ${ }^{137}$ This study will permit extension of the reportable range.

Stability studies, if required (e.g. new methodology employed and no published references), may include freeze-thaw cycle stability, $-80^{\circ} \mathrm{C},-20^{\circ} \mathrm{C}$, room temperature and time on-instrument studies. ${ }^{137}$ Reagent or sample carryover can be evaluated during precision experiments by placing the different levels of validators in specified orders (e.g. low concentration, then high, then repeat low) of testing. ${ }^{137}$ Robustness of the assay can be evaluated by including more than one lot of reagent (as well as commercial calibrators and controls) in the validation process. ${ }^{132,133,136}$

Consensus recommendations for method validation or verification of performance:

- Method validation or verification of performance is required before assays are used for clinical reporting. ${ }^{131-137}$

- Prior to performing method validation or verification, a plan (protocol) should be written that describes how the validation will be conducted and acceptance criteria. ${ }^{131,136}$

- Method validation studies should include precision, accuracy, linearity, determination of LLOQ LLOD and reportable range and may include stability studies. ${ }^{131-137}$

- Method verification of performance studies should include precision, accuracy and possibly linearity. ${ }^{135,136}$

\section{DOAC External Quality Assessment| Assurance}

Various processes can be utilized by laboratories to ensure the quality of testing, including internal quality control (IQC) and external quality assessment (EQA). ${ }^{51,138}$ IQC utilizes homogeneous samples of a predetermined nature tested by the laboratory over a period of time, at a minimum of daily or whenever testing is performed, whereas EQA is a process whereby blinded samples are dispatched to laboratories and tested in the manner in which patient samples are tested and return results to the EQA provider for analysis. Several EQA programs are currently available for DOAC assessment ( - Table 4 ). 
Table 4 External quality assurance programs for DOAC

\begin{tabular}{|l|l|l|l|}
\hline DOAC & Providers & $\begin{array}{l}\text { Qualitative } \\
\text { tests }\end{array}$ & Quantitative tests \\
\hline Dabigatran & $\begin{array}{l}\text { RCPA QAP } \\
\text { NEQAS } \\
\text { ECAT } \\
\text { CAP }\end{array}$ & $\begin{array}{l}\text { PT, APTT, } \\
\text { TT }\end{array}$ & $\begin{array}{l}\text { dTT/DTI, ECA, ECT, } \\
\text { anti-Ila, LC/MS-MS }\end{array}$ \\
\hline Rivaroxaban & $\begin{array}{l}\text { RCPA QAP } \\
\text { NEQAS } \\
\text { ECAT } \\
\text { CAP }\end{array}$ & PT, APTT & Anti-Xa, LC/MS-MS \\
\hline Apixaban & $\begin{array}{l}\text { RCPA QAP } \\
\text { NEQAS } \\
\text { ECAT } \\
\text { CAP }\end{array}$ & None & Anti-Xa, LC/MS-MS \\
\hline Edoxaban & $\begin{array}{l}\text { ECAT } \\
(2019)\end{array}$ & & \\
\hline
\end{tabular}

Abbreviations: APTT, activated partial thromboplastin time; CAP, College of American Pathologists; DTI, direct thrombin inhibitor; dTT, dilute thrombin time; ECA, ecarin chromogenic assay; ECAT, external quality control of diagnostic assays and tests; ECT, ecarin clotting time; LC/MS-MS, tandem mass spectrometry; PT, prothrombin time; RCPA QAP, Royal College of Pathologists of Australasia Quality Assurance Program; UKNEQAS, United Kingdom National External Quality Assessment Service.

All tests used by the laboratory to assess DOACs should be covered by EQA and subject to IQC. EQA helps assess the accuracy of test systems used by laboratories, as the result submitted by laboratories can potentially be compared with some predefined 'gold standard' (or 'target') result, as well as whether the laboratory test result is within an acceptable range of 'closeness' to the target. The range of acceptability is used to determine if a given laboratory's test result is within the acceptable range, or outside this range, thereby offering a means to 'assure' the quality of test results (hence, the term 'external quality assurance' is sometimes used).

It is recognized that the EQA process represents an imperfect test assessment system. First, in the peer-comparison test system, the 'trueness' of the target result is dependent on the quality of the results submitted by participants of the EQA program, and may be skewed by outliers (possibly representing poor laboratory performance) or by dominant methodologies (e.g. popular reagent kit methods). Thus, the median is usually used in preference to the average, as this is less influenced by such factors. The predetermined range of acceptability also differs according to different EQA programs, and although usually expressed as a percentage variance (e.g. 5,10 or $20 \%$ ranges around the median), this may be defined by statistical models or by expert committees. In addition to providing numerical data analysis, EQA providers should also be encouraging laboratories to interpret EQA test results in a manner that would reflect real patient test interpretation.

Any material generated for EQA or proficiency test purposes should undergo stability and homogeneity testing, and if available, some pre-dispatch testing by LC/MS-MS or a reference laboratory using a 'reference' quantitative method (e.g. dTT for dabigatran and drug-calibrated anti-Xa assays for anti-Xa DOACs).

Consensus DOAC EQA recommendations:

- Each laboratory must enrol in an EQA program specific for the DOAC being measured.

- EQA should be at a minimum two samples per dispatch, with at least two dispatches in a calendar year.

\section{What is known about this topic?}

- PT and APTT are not reliable to assess DOAC concentration.

- dTT, ECA, or ECT demonstrates linear relationship with dabigatran concentration.

- Drug-calibrated anti-Xa tests are comparable to tandem mass spectrometry measurements of anti-Xa DOACs.

\section{What does this paper add?}

ICSH document providing guidance to laboratory DOAC testing:

- Consensus recommendations for the pre-analytical phase of DOAC testing, including recommended timed collection (trough) and guidance for sample stability.

- Consensus recommendations for the analytical phase of DOAC testing, including method validation or verification of performance of DOAC test, identifying tandem mass spectrometry as the gold standard for DOAC measurement. Indicating that drug-calibrated dTT, ECA, ECT, anti-FIla and anti-FXa are suitable for rapid quantitation of DOACs, and requiring that laboratories perform IQA at a minimum of once per day of testing.

- Consensus recommendations for the post-analytical phase of DOAC testing, including that DOAC results are reported in $\mathrm{ng} / \mathrm{mL}$, and the reported results are accompanied with published (trough) range of results, and requiring that laboratories that perform DOAC testing must participate in external QAP to assure continuous quality assurance.

Conflicts of Interest

RCG: Advisory board for Instrumentation Laboratory, Roche Diagnostics, NovoNordisk, and Boehringer Ingelheim; Speaker honoraria for Siemans Healthcare Diagnostics, expert testimony on rivaroxaban and dabigatran. DMA: Advisory board for NovoNordisk, Baxalta, Bayer Healthcare; speaker honoraria from Siemens Healthcare Diagnostics, consulting for rivaroxaban litigation.

SB: Grants and research: site investigator Bayer (RASET) study, partial salary support for endowed chair funded in part by Eli Lilly, Canada.

JD: Advisory board: Bayer, travel awards and/or speaker honoraria: Daichii Sankyo; Diagnostica Stago, Roche Diagnostics. 


\section{EF: None}

IG-T: Advisory boards and speaker honoraria: Bayer Healthcare, Boehringer Ingelheim, Bristol-Myers-Squibb/ Pfizer.

CG: Advisory board Werfen; speaker honoraria: Roche Diagnostics, Werfen.

YK: Advisory board and consultant: Daichii Sankyo.

EL-L: Advisory boards: Bayer Healthcare, Boeh.

\section{References}

1 European Medicines Agency- Pradaxa - Procedure EMEA/H/C/829. Available at: http://www.ema.europa.eu/docs/en_GB/document_library/EPAR_-Public_assessment_report/human/000829/WC5 00041062.pdf. Accessed February 28, 2017

2 Dale BJ, Chan NC, Eikelboom JW. Laboratory measurement of the direct oral anticoagulants. Br J Haematol 2016;172(03):315-336

3 Douxfils J, Gosselin RC. Laboratory assessment of direct oral anticoagulants (DOACs). Semin Thromb Hemost 2017;43(03): 277-290

4 Pradaxa [package insert]. Boehringer Ingelheim Pharmaceuticals Inc, Ingelheim am Rhein, Germany. Revised November 2015. Accessed December 31, 2016

5 Blech S, Ebner T, Ludwig-Schwellinger E, Stangier J, Roth W. The metabolism and disposition of the oral direct thrombin inhibitor, dabigatran, in humans. Drug Metab Dispos 2008;36(02):386-399

6 Wienen W, Stassen JM, Priepke H, Ries UJ, Hauel N. In-vitro profile and ex-vivo anticoagulant activity of the direct thrombin inhibitor dabigatran and its orally active prodrug, dabigatran etexilate. Thromb Haemost 2007;98(01):155-162

7 Stangier J. Clinical pharmacokinetics and pharmacodynamics of the oral direct thrombin inhibitor dabigatran etexilate. Clin Pharmacokinet 2008;47(05):285-295

8 Stangier J, Rathgen K, Stähle H, Gansser D, Roth W. The pharmacokinetics, pharmacodynamics and tolerability of dabigatran etexilate, a new oral direct thrombin inhibitor, in healthy male subjects. Br J Clin Pharmacol 2007;64(03):292-303

9 Samuelson BT, Cuker A. Measurement and reversal of the direct oral anticoagulants. Blood Rev 2017;31(01):77-84

10 Reilly PA, Lehr T, Haertter S, et al; RE-LY Investigators. The effect of dabigatran plasma concentrations and patient characteristics on the frequency of ischemic stroke and major bleeding in atrial fibrillation patients: the RE-LY Trial (Randomized Evaluation of Long-Term Anticoagulation Therapy). J Am Coll Cardiol 2014;63 (04):321-328

11 Perzborn E, Strassburger J, Wilmen A, et al. In vitro and in vivo studies of the novel antithrombotic agent BAY 59-7939-an oral, direct Factor Xa inhibitor. J Thromb Haemost 2005;3(03):514-521

12 Depasse F, Busson J, Mnich J, Le Flem L, Gerotziafas GT, Samama MM. Effect of BAY 59-7939-a novel, oral, direct Factor Xa inhibitor - on clot-bound Factor Xa activity in vitro. J Thromb Haemost 2005;3(Suppl 1):Abstract P1104

13 Kubitza D, Perzborn E, Berkowitz SD. The discovery of rivaroxaban: translating preclinical assessments into clinical practice. Front Pharmacol 2013;4:145

14 European Medicines Agency. Xarelto - Summary of Product Characteristics. Available at: http://www.ema.europa.eu/docs/ en_GB/document_library/EPAR_-_Product_Information/ human/000944/WC500057108.pdf. Accessed January 15, 2017

15 Mueck W, Stampfuss J, Kubitza D, Becka M. Clinical pharmacokinetic and pharmacodynamic profile of rivaroxaban. Clin Pharmacokinet 2014;53(01):1-16

16 Food and Drug Administration. Xarelto-Prescribing Information. Available at: http://www.accessdata.fda.gov/drugsatfda_docs/label/2011/202439s001lbl.pdf. Accessed January 15, 2017
17 Zhang D, He K, Raghavan N, et al. Comparative metabolism of 14C-labeled apixaban in mice, rats, rabbits, dogs, and humans. Drug Metab Dispos 2009;37(08):1738-1748

18 Mani H, Lindhoff-Last E. New oral anticoagulants in patients with nonvalvular atrial fibrillation: a review of pharmacokinetics, safety, efficacy, quality of life, and cost effectiveness. Drug Des Devel Ther 2014;8:789-798

19 European Medicines Agency. Eliquis - Summary of Product Characteristics. Available at: http://www.ema.europa.eu/docs/ en_GB/document_library/EPAR_-_Product_Information/ human/002148/WC500107728.pdf. Accessed January 15, 2017

20 Furugohri T, Isobe K, Honda Y, et al. DU-176b, a potent and orally active factor Xa inhibitor: in vitro and in vivo pharmacological profiles. J Thromb Haemost 2008;6(09):1542-1549

21 Ogata K, Mendell-Harary J, Tachibana M, et al. Clinical safety, tolerability, pharmacokinetics, and pharmacodynamics of the novel factor Xa inhibitor edoxaban in healthy volunteers. J Clin Pharmacol 2010;50(07):743-753

22 Giugliano RP, Ruff CT, Braunwald E, et al; ENGAGE AF-TIMI 48 Investigators. Edoxaban versus warfarin in patients with atrial fibrillation. N Engl J Med 2013;369(22):2093-2104

23 Büller HR, Décousus H, Grosso MA, et al; Hokusai-VTE Investigators. Edoxaban versus warfarin for the treatment of symptomatic venous thromboembolism. N Engl J Med 2013;369(15): 1406-1415

24 Fuji T, Wang CJ, Fujita S, Kawai Y, Kimura T, Tachibana S. Safety and efficacy of edoxaban, an oral factor Xa inhibitor, for thromboprophylaxis after total hip arthroplasty in Japan and Taiwan. J Arthroplasty 2014;29(12):2439-2446

25 Fuji T, Wang CJ, Fujita S, et al. Safety and efficacy of edoxaban, an oral factor Xa inhibitor, versus enoxaparin for thromboprophylaxis after total knee arthroplasty: the STARS E-3 trial. Thromb Res 2014;134(06):1198-1204

26 Weitz JI, Connolly SJ, Patel I, et al. Randomised, parallel-group, multicentre, multinational phase 2 study comparing edoxaban, an oral factor Xa inhibitor, with warfarin for stroke prevention in patients with atrial fibrillation. Thromb Haemost 2010;104(03): 633-641

27 Ruff CT, Giugliano RP, Braunwald E, et al. Association between edoxaban dose, concentration, anti-Factor Xa activity, and outcomes: an analysis of data from the randomised, double-blind ENGAGE AF-TIMI 48 trial. Lancet 2015;385(9984):2288-2295

28 Verhamme P, Wells PS, Segers A, et al. Dose reduction of edoxaban preserves efficacy and safety for the treatment of venous thromboembolism. An analysis of the randomised, double-blind HOKUSAI VTE trial. Thromb Haemost 2016;116(04):747-753

29 Fuji T, Fujita S, Kawai Y, et al. Safety and efficacy of edoxaban in patients undergoing hip fracture surgery. Thromb Res 2014;133 (06):1016-1022

30 Gosselin RC, Adcock DM. The laboratory's 2015 perspective on direct oral anticoagulant testing. J Thromb Haemost 2016;14 (05):886-893

31 Adams HP Jr, del Zoppo G, Alberts MJ, Bhatt DL, Brass L, Furlan A, Grubb RL, Higashida RT, Jauch EC, Kidwell C, Lyden PD, Morgenstern LB, Qureshi AI, Rosenwasser RH, Scott PA, Wijdicks EF; American Heart Association; American Stroke Association Stroke Council; Clinical Cardiology Council; Cardiovascular Radiology and Intervention Council; Atherosclerotic Peripheral Vascular Disease and Quality of Care Outcomes in Research Interdisciplinary Working Groups. Guidelines for the early management of adults with ischemic stroke: a guideline from the American Heart Association/American Stroke Association Stroke Council, Clinical Cardiology Council, Cardiovascular Radiology and Intervention Council, and the Atherosclerotic Peripheral Vascular Disease and Quality of Care Outcomes in Research Interdisciplinary Working Groups: the American Academy of Neurology affirms the value of this guideline as an educational tool for neurologists. Stroke 2007;38(05): 1655-711. Epub 2007 Apr 12. Erratum in: Stroke. 2007 Jun;38(6) 
32 Harenberg J, Krämer S, Du S, et al. Measurement of rivaroxaban and apixaban in serum samples of patients. Eur J Clin Invest 2014;44(08):743-752

33 McGrail R, Revsholm J, Nissen PH, Grove EL, Hvas AM. Stability of direct oral anticoagulants in whole blood and plasma from patients in steady state treatment. Thromb Res 2016;148:107-110

34 Gous T, Couchman L, Patel JP, Paradzai C, Arya R, Flanagan RJ. Measurement of the direct oral anticoagulants apixaban, dabigatran, edoxaban, and rivaroxaban in human plasma using turbulent flow liquid chromatography with high-resolution mass spectrometry. Ther Drug Monit 2014;36(05):597-605

35 Lessire S, Douxfils J, Baudar J, et al. Is Thrombin Time useful for the assessment of dabigatran concentrations? An in vitro and ex vivo study. Thromb Res 2015;136(03):693-696

36 Gosselin RC, Adcock D, Hawes EM, Francart SJ, Grant RP, Moll S. Evaluating the use of commercial drug-specific calibrators for determining PT and APTT reagent sensitivity to dabigatran and rivaroxaban. Thromb Haemost 2015;113(01):77-84

37 Harenberg J, Marx S, Diener H-C, et al. Comparison of efficacy and safety of dabigatran, rivaroxaban and apixaban in patients with atrial fibrillation using network meta-analysis. Int Angiol 2012; 31(04):330-339

38 van Ryn J, Stangier J, Haertter S, et al. Dabigatran etexilate-a novel, reversible, oral direct thrombin inhibitor: interpretation of coagulation assays and reversal of anticoagulant activity. Thromb Haemost 2010;103(06):1116-1127

39 Samama MM, Contant G, Spiro TE, et al; Rivaroxaban Prothrombin Time Field Trial Laboratories. Evaluation of the prothrombin time for measuring rivaroxaban plasma concentrations using calibrators and controls: results of a multicenter field trial. Clin Appl Thromb Hemost 2012;18(02):150-158

40 Douxfils J, Mullier F, Loosen C, Chatelain C, Chatelain B, Dogné JM. Assessment of the impact of rivaroxaban on coagulation assays: laboratory recommendations for the monitoring of rivaroxaban and review of the literature. Thromb Res 2012;130 (06):956-966

41 Douxfils J, Mullier F, Robert S, Chatelain C, Chatelain B, Dogné J-M. Impact of dabigatran on a large panel of routine or specific coagulation assays. Laboratory recommendations for monitoring of dabigatran etexilate. Thromb Haemost 2012;107(05):985-997

42 Halbmayer W-M, Weigel G, Quehenberger P, et al. Interference of the new oral anticoagulant dabigatran with frequently used coagulation tests. Clin Chem Lab Med 2012;50(09):1601-1605

43 Hillarp A, Baghaei F, Fagerberg Blixter I, et al. Effects of the oral, direct factor Xa inhibitor rivaroxaban on commonly used coagulation assays. J Thromb Haemost 2011;9(01):133-139

$44 \mathrm{Mani}$ H. Interpretation of coagulation test results under direct oral anticoagulants. Int J Lab Hematol 2014;36(03):261-268

45 Kitchen S, Gray E, Mackie I, Baglin T, Makris M; BCSH Committee. Measurement of non-coumarin anticoagulants and their effects on tests of Haemostasis: Guidance from the British Committee for Standards in Haematology. Br J Haematol 2014;166(06):830-841

46 Van Blerk M, Bailleul E, Chatelain B, et al. Influence of dabigatran and rivaroxaban on routine coagulation assays. A nationwide Belgian survey. Thromb Haemost 2015;113(01):154-164

47 Testa S, Legnani C, Tripodi A, et al. Poor comparability of coagulation screening test with specific measurement in patients receiving direct oral anticoagulants: results from a multicenter/multiplatform study. J Thromb Haemost 2016;14 (11):2194-2201

48 Hawes EM, Deal AM, Funk-Adcock D, et al. Performance of coagulation tests in patients on therapeutic doses of dabigatran: a crosssectional pharmacodynamic study based on peak and trough plasma levels. J Thromb Haemost 2013;11(08):1493-1502

49 Gouin-Thibault I, Flaujac C, Delavenne X, et al. Assessment of apixaban plasma levels by laboratory tests: suitability of three anti-Xa assays. A multicentre French GEHT study. Thromb Haemost 2014;111(02):240-248
50 Douxfils J, Chatelain C, Chatelain B, Dogné J-M, Mullier F. Impact of apixaban on routine and specific coagulation assays: a practical laboratory guide. Thromb Haemost 2013;110(02):283-294

51 Bonar R, Favaloro EJ, Mohammed S, et al. The effect of the direct factor Xa inhibitors apixaban and rivaroxaban on haemostasis tests: a comprehensive assessment using in vitro and ex vivo samples. Pathology 2016;48(01):60-71

52 Cuker A, Siegal DM, Crowther MA, Garcia DA. Laboratory measurement of the anticoagulant activity of the non-vitamin K oral anticoagulants. J Am Coll Cardiol 2014;64(11):1128-1139

53 Douxfils J, Chatelain B, Chatelain C, Dogné J-M, Mullier F. Edoxaban: impact on routine and specific coagulation assays. A practical laboratory guide. Thromb Haemost 2016;115(02): 368-381

54 Zafar MU, Vorchheimer DA, Gaztanaga J, et al. Antithrombotic effects of factor Xa inhibition with DU-176b: Phase-I study of an oral, direct factor Xa inhibitor using an ex-vivo flow chamber. Thromb Haemost 2007;98(04):883-888

55 Morishima Y, Kamisato C. Laboratory measurements of the oral direct factor Xa inhibitor edoxaban: comparison of prothrombin time, activated partial thromboplastin time, and thrombin generation assay. Am J Clin Pathol 2015;143(02):241-247

56 Helin TA, Pakkanen A, Lassila R, Joutsi-Korhonen L. Laboratory assessment of novel oral anticoagulants: method suitability and variability between coagulation laboratories. Clin Chem 2013;59 (05):807-814

57 Tripodi A, Chantarangkul V, Guinet C, Samama MM. The International Normalized Ratio calibrated for rivaroxaban has the potential to normalize prothrombin time results for rivaroxaban-treated patients: results of an in vitro study. J Thromb Haemost 2011;9(01):226-228

58 Jabet A, Stepanian A, Golmard JL, Flaujac C, Joly BS, GouinThibault I, Siguret V. Are Screening Tests Reliable to Rule Out Direct Oral Anticoagulant Plasma Levels at Various Thresholds $(30,50$, or $100 \mathrm{ng} / \mathrm{mL})$ in Emergency Situations? Chest. 2018; 153 (01):288-290

59 Francart SJ, Hawes EM, Deal AM, et al. Performance of coagulation tests in patients on therapeutic doses of rivaroxaban. A crosssectional pharmacodynamic study based on peak and trough plasma levels. Thromb Haemost 2014;111(06):1133-1140

60 Tsutsumi Y, Shimono J, Ohhigashi H, Ito S, Shiratori S, Teshima T; Int J Lab. Analysis of the influence of dabigatran on coagulation factors and inhibitors. Int J Lab Hematol 2015;37(02):225-230

61 Gosselin RC, Adcock DM. Comment: analysis of the influence of dabigatran on coagulation factors and inhibitors. Int J Lab Hematol 2016;38(01):e4

62 Gosselin R, Grant RP, Adcock DM. Comparison of the effect of the anti-Xa direct oral anticoagulants apixaban, edoxaban, and rivaroxaban on coagulation assays. Int J Lab Hematol 2016;38 (05):505-513

63 Dager WE, Gosselin RC, Kitchen S, Dwyre D. Dabigatran effects on the international normalized ratio, activated partial thromboplastin time, thrombin time, and fibrinogen: a multicenter, in vitro study. Ann Pharmacother 2012;46(12):1627-1636

64 Dias JD, Norem K, Doorneweerd DD, Thurer RL, Popovsky MA, Omert LA. Use of thromboelastography (TEG) for detection of new oral anticoagulants. Arch Pathol Lab Med 2015;139(05): 665-673

65 Herrmann R, Thom J, Wood A, Phillips M, Muhammad S, Baker R. Thrombin generation using the calibrated automated thrombinoscope to assess reversibility of dabigatran and rivaroxaban. Thromb Haemost 2014;111(05):989-995

66 Adelmann D, Wiegele M, Wohlgemuth RK, et al. Measuring the activity of apixaban and rivaroxaban with rotational thrombelastometry. Thromb Res 2014;134(04):918-923

67 Chojnowski K, Górski T, Robak M, Treliński J. Effects of rivaroxaban therapy on ROTEM coagulation parameters in patients with venous thromboembolism. Adv Clin Exp Med 2015;24(06):995-1000 
68 Körber MK, Langer E, Köhr M, Wernecke KD, Korte W, von Heymann C. In vitro and ex vivo measurement of prophylactic dabigatran concentrations with a new ecarin-based thromboelastometry test. Transfus Med Hemother 2017;44(02):100-105

69 Fontana P, Alberio L, Angelillo-Scherrer A, et al. Impact of rivaroxaban on point-of-care assays. Thromb Res 2017;153:65-70

70 Ebner M, Peter A, Spencer C, et al. Point-of-care testing of coagulation in patients treated with non-vitamin $\mathrm{K}$ antagonist oral anticoagulants. Stroke 2015;46(10):2741-2747

71 Al-Aieshy F, Malmström RE, Antovic J, et al. Clinical evaluation of laboratory methods to monitor exposure of rivaroxaban at trough and peak in patients with atrial fibrillation. Eur J Clin Pharmacol 2016;72(06):671-679

72 Mani $\mathrm{H}$, Herth $\mathrm{N}$, Kasper A, et al. Point-of-care coagulation testing for assessment of the pharmacodynamic anticoagulant effect of direct oral anticoagulant. Ther Drug Monit 2014;36(05): 624-631

73 Ebner M, Birschmann I, Peter A, et al. Point-of-care testing for emergency assessment of coagulation in patients treated with direct oral anticoagulants. Crit Care 2017;21(01):32

74 Hemachron Jr Whole Blood Microcoagulation system. Prothrombin time (PT) [package insert]. Edison, NJ: International Technidyne Corporation Revision March 2007

75 Du S, Weiss C, Christina G, et al. Determination of dabigatran in plasma, serum, and urine samples: comparison of six methods. Clin Chem Lab Med 2015;53(08):1237-1247

76 DOASENSE GmbH. Heidelberg, Germany. 2017 https://www.doasense.de/Press_Release_of_DOASENSE_GmbH.PDF

77 Vogeser M, Seger C. A decade of HPLC-MS/MS in the routine clinical laboratory-goals for further developments. Clin Biochem 2008;41(09):649-662

78 Adaway JE, Keevil BG. Therapeutic drug monitoring and LC-MS/ MS. J Chromatogr B Analyt Technol Biomed Life Sci $2012883-$ 884:33-49

79 Kubitza D, Becka M, Wensing G, Voith B, Zuehlsdorf M. Safety, pharmacodynamics, and pharmacokinetics of BAY 59-7939-an oral, direct Factor Xa inhibitor-after multiple dosing in healthy male subjects. Eur J Clin Pharmacol 2005;61(12):873-880

80 Rohde G. Determination of rivaroxaban-a novel, oral, direct Factor Xa inhibitor-in human plasma by high-performance liquid chromatography-tandem mass spectrometry. J Chromatogr B Analyt Technol Biomed Life Sci 2008;872(1-2):43-50

81 Barrett YC, Wang J, Song Y, et al. A randomised assessment of the pharmacokinetic, pharmacodynamic and safety interaction between apixaban and enoxaparin in healthy subjects. Thromb Haemost 2012;107(05):916-924

82 Bathala MS, Masumoto H, Oguma T, He L, Lowrie C, Mendell J. Pharmacokinetics, biotransformation, and mass balance of edoxaban, a selective, direct factor Xa inhibitor, in humans. Drug Metab Dispos 2012;40(12):2250-2255

83 Schmitz EM, Boonen K, van den Heuvel DJ, et al. Determination of dabigatran, rivaroxaban and apixaban by ultra-performance liquid chromatography - tandem mass spectrometry (UPLCMS/MS) and coagulation assays for therapy monitoring of novel direct oral anticoagulants. J Thromb Haemost 2014;12(10): 1636-1646

84 Douxfils J, Dogné JM, Mullier F, et al. Comparison of calibrated dilute thrombin time and aPTT tests with LC-MS/MS for the therapeutic monitoring of patients treated with dabigatran etexilate. Thromb Haemost 2013;110(03):543-549

85 Douxfils J, Tamigniau A, Chatelain B, et al. Comparison of calibrated chromogenic anti-Xa assay and PT tests with LC-MS/ MS for the therapeutic monitoring of patients treated with rivaroxaban. Thromb Haemost 2013;110(04):723-731

86 Antovic JP, Skeppholm M, Eintrei J, et al. Evaluation of coagulation assays versus LC-MS/MS for determinations of dabigatran concentrations in plasma. Eur J Clin Pharmacol 2013;69(11): $1875-1881$
87 Skeppholm M, Hjemdahl P, Antovic JP, et al. On the monitoring of dabigatran treatment in "real life" patients with atrial fibrillation. Thromb Res 2014;134(04):783-789

88 Skeppholm M, Al-Aieshy F, Berndtsson M, et al. Clinical evaluation of laboratory methods to monitor apixaban treatment in patients with atrial fibrillation. Thromb Res 2015;136(01):148-153

89 Vogeser M, Seger C. Pitfalls associated with the use of liquid chromatography-tandem mass spectrometry in the clinical laboratory. Clin Chem 2010;56(08):1234-1244

90 Annesley T, Majzoub J, Hsing A, Wu A, Rockwood A, Mason D. Mass spectrometry in the clinical laboratory: how have we done, and where do we need to be? Clin Chem 2009;55(06):1236-1239

91 Clarke W, Rhea JM, Molinaro R. Challenges in implementing clinical liquid chromatography-tandem mass spectrometry methods-the light at the end of the tunnel. J Mass Spectrom 2013;48(07):755-767

92 Nowak G. The ecarin clotting time, a universal method to quantify direct thrombin inhibitors. Pathophysiol Haemost Thromb 2003;33(04):173-183

93 Pötzsch B, Hund S, Madlener K, Unkrig C, Müller-Berghaus G. Monitoring of recombinant hirudin: assessment of a plasma-based ecarin clotting time assay. Thromb Res 1997;86(05):373-383

94 Lindhoff-Last E, Piechottka GP, Rabe F, Bauersachs R. Hirudin determination in plasma can be strongly influenced by the prothrombin level. Thromb Res 2000;100(01):55-60

95 Gosselin R, Hawes E, Moll S, Adcock D. Performance of various laboratory assays in the measurement of dabigatran in patients receiving therapeutic doses: a prospective study based on peak and trough plasma levels. Am J Clin Pathol 2014;141(02):262-267

96 Lange U, Nowak G, Bucha E. Ecarin chromogenic assay-a new method for quantitative determination of direct thrombin inhibitors like hirudin. Pathophysiol Haemost Thromb 2003;33(04):184-191

97 Douxfils J, Lessire S, Dincq AS, et al. Estimation of dabigatran plasma concentrations in the perioperative setting. An ex vivo study using dedicated coagulation assays. Thromb Haemost 2015;113(04):862-869

98 Biophen DTI [package insert]. Neuville-sur-Oise, France: Hyphen Biomedical. Revision April 29, 2015

99 Helin TA, Lemponen M, Hjemdahl P, Rönquist-Nii Y, Lassila R, Joutsi-Korhonen L. From laboratory to clinical practice: dabigatran effects on thrombin generation and coagulation in patient samples. Thromb Res 2015;136(01):154-160

100 Love JE, Ferrell C, Chandler WL. Monitoring direct thrombin inhibitors with a plasma diluted thrombin time. Thromb Haemost 2007;98(01):234-242

101 Avecilla ST, Ferrell C, Chandler WL, Reyes M. Plasma-diluted thrombin time to measure dabigatran concentrations during dabigatran etexilate therapy. Am J Clin Pathol 2012;137(04):572-574

102 Stangier J, Feuring M. Using the HEMOCLOT direct thrombin inhibitor assay to determine plasma concentrations of dabigatran. Blood Coagul Fibrinolysis 2012;23(02):138-143

103 Hemoclot Thrombin Inhibitors [package insert]. Neuville-surOise, France: Hyphen Biomedical. Revision March 17, 2015

104 HemosIL Direct Thrombin Inhibitors [package insert]. Bedford, MA: Instrumentation Laboratory. Revision March 2016

105 Douxfils J, Mani H, Minet V, et al. Non-VKA oral anticoagulants: accurate measurement of plasma drug concentrations. BioMed Res Int 2015;2015:345138

106 Douxfils J, Tamigniau A, Chatelain B, Goffinet C, Dogné JM, Mullier F. Measurement of non-VKA oral anticoagulants versus classic ones: the appropriate use of hemostasis assays. Thromb J 2014;12:24

107 Becker RC, Alexander JH, Newby LK, et al. Effect of apixaban, an oral and direct factor Xa inhibitor, on coagulation activity biomarkers following acute coronary syndrome. Thromb Haemost 2010;104(05):976-983

108 Becker RC, Yang H, Barrett Y, et al. Chromogenic laboratory assays to measure the factor Xa-inhibiting properties of apixaban-an 
oral, direct and selective factor Xa inhibitor. J Thromb Thrombolysis 2011;32(02):183-187

109 Douxfils J, Chatelain B, Hjemdahl P, et al. Does the Russell viper venom time test provide a rapid estimation of the intensity of oral anticoagulation? A cohort study. Thromb Res 2015;135(05):852-860

110 Gosselin RC, Adcock Funk DM, Taylor JM, et al. Comparison of anti-Xa and dilute Russell viper venom time assays in quantifying drug levels in patients on therapeutic doses of rivaroxaban. Arch Pathol Lab Med 2014;138(12):1680-1684

111 Hillarp A, Gustafsson KM, Faxälv L, et al. Effects of the oral, direct factor Xa inhibitor apixaban on routine coagulation assays and anti-FXa assays. J Thromb Haemost 2014;12(09):1545-1553

112 Mani H, Hesse C, Stratmann G, Lindhoff-Last E. Ex vivo effects of low-dose rivaroxaban on specific coagulation assays and coagulation factor activities in patients under real life conditions. Thromb Haemost 2013;109(01):127-136

113 Lindhoff-Last E, Samama MM, Ortel TL, Weitz JI, Spiro TE. Assays for measuring rivaroxaban: their suitability and limitations. Ther Drug Monit 2010;32(06):673-679

114 Samama MM, Amiral J, Guinet C, Perzborn E, Depasse F. An optimised, rapid chromogenic assay, specific for measuring direct factor Xa inhibitors (rivaroxaban) in plasma. Thromb Haemost 2010;104(05):1078-1079

115 Samama MM, Contant G, Spiro TE, et al; Rivaroxaban Anti-Factor Xa Chromogenic Assay Field Trial Laboratories. Evaluation of the anti-factor Xa chromogenic assay for the measurement of rivaroxaban plasma concentrations using calibrators and controls. Thromb Haemost 2012;107(02):379-387

116 Samama MM, Guinet C, Le Flem L, Ninin E, Debue JM. Measurement of dabigatran and rivaroxaban in primary prevention of venous thromboembolism in 106 patients, who have undergone major orthopedic surgery: an observational study. J Thromb Thrombolysis 2013;35(02):140-146

117 Samama MM, Martinoli JL, LeFlem L, et al. Assessment of laboratory assays to measure rivaroxaban-an oral, direct factor Xa inhibitor. Thromb Haemost 2010;103(04):815-825

118 Samama MM, Mendell J, Guinet C, Le Flem L, Kunitada S. In vitro study of the anticoagulant effects of edoxaban and its effect on thrombin generation in comparison to fondaparinux. Thromb Res 2012;129(04):e77-e82

119 Lessire S, Douxfils J, Pochet L, et al. Estimation of rivaroxaban plasma concentrations in the perioperative setting in patients with or without heparin bridging. Clin Appl Thromb Hemost 2018;24(01):129-138

120 Mani H, Rohde G, Stratmann G, et al. Accurate determination of rivaroxaban levels requires different calibrator sets but not addition of antithrombin. Thromb Haemost 2012;108(01):191-198

121 Gosselin RC, Francart SJ, Hawes EM, Moll S, Dager WE, Adcock DM. Heparin-calibrated chromogenic anti-Xa activity measurements in patients receiving rivaroxaban: can this test be used to quantify drug level? Ann Pharmacother 2015;49(07):777-783

122 Yates SG, Smith S, Tharpe W, Shen YM, Sarode R. Can an anti-Xa assay for low-molecular-weight heparin be used to assess the presence of rivaroxaban? Transfus Apheresis Sci 2016;55(02):212-215
123 Adcock DM, Gosselin R. Direct oral anticoagulants (DOACs) in the laboratory: 2015 review. Thromb Res 2015;136(01):7-12

224 Sabor L, Raphaël M, Dogné JM, Mullier F, Douxfils J. Heparincalibrated chromogenic anti-Xa assays are not suitable to assess the presence of significant direct factor Xa inhibitors levels. Thromb Res 2017;156:36-38

125 Harenberg J, Du S, Krämer S, et al. Novel methods for assessing oral direct factor Xa and thrombin inhibitors: use of point-ofcare testing and urine samples. Semin Thromb Hemost 2013;39 (01):66-71

126 Harenberg J, Krämer S, Du S, Weiss C, Krämer R. Concept of a point of care test to detect new oral anticoagulants in urine samples. Thromb J 2013;11(01):15

127 Harenberg J, Du S, Wehling M, et al. Measurement of dabigatran, rivaroxaban and apixaban in samples of plasma, serum and urine, under real life conditions. An international study. Clin Chem Lab Med 2016;54(02):275-283

128 Harris LF, Rainey P, Castro-López V, O’Donnell JS, Killard AJ. A microfluidic anti-Factor Xa assay device for point of care monitoring of anticoagulation therapy. Analyst (Lond) 2013; 138(17):4769-4776

129 Bluecher A, Meyer Dos Santos S, Ferreirós N, et al. Microfluidic coagulation assay for monitoring anticoagulant therapy in acute stroke patients. Thromb Haemost 2017;117(03):519-528

130 Specific PoC Testing of Coagulation in Patients Treated With NOAC 1 (SPOCT-NOAC 1) [Identifier: NCT02825394]. Available at: www.clinicaltrials.gov. Accessed January 15, 2017

131 FDA. Guidance for Industry Bioanalytical Method Validation. 2001, Revised 2013. Available at: http://www.fda.gov/Drugs/ GuidanceComplianceRegulatoryInformation/Guidances/default. htm. Accessed January 15, 2017

132 Validation of Analytical Procedures: Text and Methodology Q2 (R1). ICH harmonised tripartite guideline. 2005. Available at: www.ich.org. Accessed January 15, 2017

133 Guidance for Industry Q2B Validation of Analytical Procedures: Methodology. 1996. Available at: http://www.fda.gov/cder/guidance/index.htm. Accessed January 15, 2017

134 US Department of Health and Human Services. Clinical laboratory improvement amendments of 1988: final rule. Fed Regist 1992;57(40):7001-7186. Codified at 42 CFR §1405-494

135 Thompson M, Ellison S, Wood R. Harmonized guidelines for single-laboratory validation of methods of analysis (IUPAC Technical Report). Pure Appl Chem 2002;74:835-855

136 Magnussen B, Örnemark U (eds.). The fitness for purpose of analytical methods. A laboratory guide to method validation and related topics. 2nd edition. Eurachem, 2014. ISBN 978-918746159-0) (www.eurachem.org)

137 Guideline on bioanalytical method validation EMEA/CHMP/EWP/ 192217/2009 Rev. 1 Corr. 2 http://www.ema.europa.eu/docs/en_GB/ document_library/Scientific_guideline/2011/08/WC500109686.pdf

138 Bonar R, Favaloro EJ, Mohammed S, Pasalic L, Sioufi J, Marsden K. The effect of dabigatran on haemostasis tests: a comprehensive assessment using in vitro and ex vivo samples. Pathology 2015; 47(04):355-364 